\title{
Morphometric analysis of significant vascular structures in posterior disc surgery with computed tomography angiography
}

\author{
(1) Emre Muhittin Altunrende, M.D., ${ }^{1}$ 는 Elif Evrim Ekin, M.D. ${ }^{2}$
}

\begin{abstract}
1'Department of Neurosurgery, Health Science University, Gaziosmanpaşa Taksim Training and Research Hospital, İstanbul-Turkey 2Department of Radiology, Health Science University, Gaziosmanpaşa Taksim Training and Research Hospital, İstanbul-Turkey
\end{abstract}

\begin{abstract}
BACKGROUND: Vascular injuries, which are rarely seen in all spinal area procedures, especially lumbar disc surgery, are vitally important. The relationship between the course of the iliac artery and vein and intervertebral disc distance was studied morphometrically in patients who had undergone computed tomography angiography for abdominal aorta.

METHODS: This study was carried out retrospectively. A total of 100 patients who had undergone computed tomography angiography participated in the study. The aorta bifurcation, right and left common iliac artery (R/LCIA) and vein (R/LCIV), and the location of the common iliac artery bifurcation were investigated. The location of these vascular structures at the level of the spinal vertebral body and at the intervertebral disc level, determination of a fat plane between them, and the anterior longitudinal ligament (ALL) were analyzed.

RESULTS: At the L4-5 intertransversarius dorsalis (IDL), the RCIV was determined to be at the 12 o'clock position RCIA in 5 I\% of cases and between the ratio of $67 \%$ ALL. The LCIA was at the I o'clock position in $72 \%$ and adjacent to the ALL in $47 \%$. The RCIV was located in the II o'clock position and there was no fat plane between the RCIV and the ALL in $92 \%$. In $80 \%$, the LCIV was located at the II-I 2 o'clock position and in 18\% transversely along the I2-I-2 o'clock region. There was no fat plane between the LCIV and the ALL in any patient. At the L5-SI IDL, the RCIA was observed at the 10 o'clock position in $63 \%$, and there was no fat plane between the RCIA and the ALL. The LCIA was at the 2 o'clock position in $72 \%$ and the LCIV was between the ALL and the LCIA in $92 \%$. The RCIV was located at the 9-10 o'clock position in $95 \%$ and no fat plane was found between the ALL and the RCIV in $60 \%$. The LCIV was located at the I-2 o'clock position in $96 \%$ and there was no fat plane between the LCIV and the ALL in 92\%; it was located close to the ALL.
\end{abstract}

CONCLUSION: The L4-5 IDL RCIA was located at the midline and at a $30^{\circ}$ angle position. The LCIV was located between them. The L5-SI IDL located at LCIA left at $60^{\circ}$ position was quite close to ALL with LCIV. When the distance from the ALL was compared and the frequency of fat planes between the ALL and the CIAs are considered, it can be noted that the RCIA in the L4-L5 IDL $(p<0.00 \mathrm{I})$ and the LCIA in the L5-SI IDL $(\mathrm{p}<0.00 \mathrm{I})$ were located remotely and in a more protected position. It should be kept in mind that the LCIV can progress along the L4-5 ID level, adjacent to the ALL, as well as transversely.

Keywords: latrogenic vascular injury; iliac artery injury; lumbar disc surgery; spinal surgery.

\section{INTRODUCTION}

Abdominal aorta at L4 vertebra level is generally divided into common iliac arteries. Common iliac arteries are separated at sacroiliac joint level with external and internal iliac arteries. Common iliac veins generally unite at the right of midline at
L4-5 intervertebral disc level (IDL) and create inferior vena cava. Relatively fatal vascular injuries can be encountered even though they are rare in intravascular intervention and surgical procedures toward lumbar vertebra. ${ }^{[1,2]}$ Lumbar disc surgery associated with vascular injuries most frequently occurs in $51.2 \% \mathrm{CIA}$, then $23.3 \% \mathrm{CIV}, 9.3 \%$ inferior vena cava,

Cite this article as: Altunrende EM, Ekin EE. Morphometric analysis of significant vascular structures in posterior disc surgery with computed tomography angiography. Ulus Travma Acil Cerrahi Derg 2019;25:105-110.

Address for correspondence: Emre Muhittin Altunrende, M.D.

SBÜ, Gaziosmanpaşa Taksim Eğitim ve Araştırma Hastanesi, Beyin ve Sinir Cerrahisi Kliniği, İstanbul, Turkey.

Tel: +90 212 - 27246 I5 E-mail: mealtunrende@msn.com 


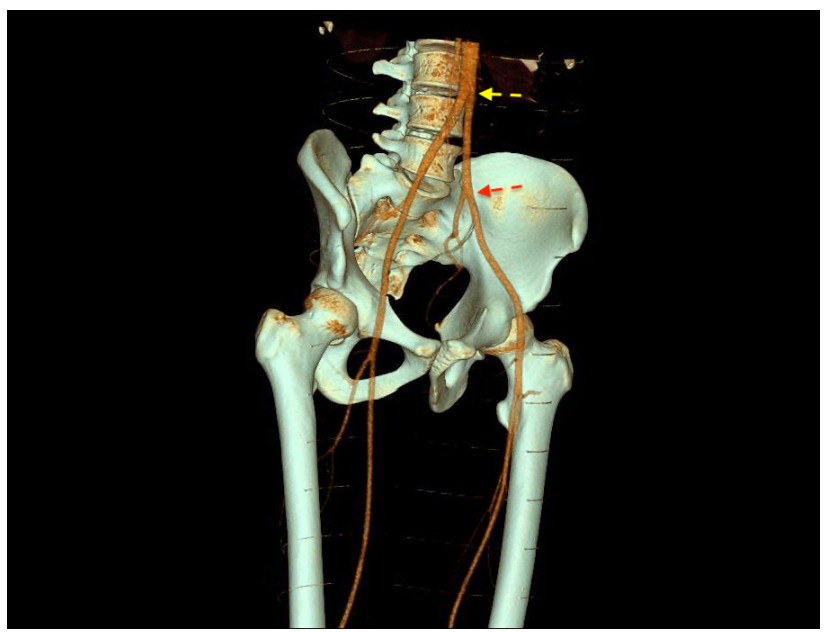

Figure 1. A 22-year-old man; volume-rendered 3D reconstruction image clearly depicts the distal abdominal aorta and both iliac artery. This oblique sagittal image demonstrates $A B$ at the $L 4$ VB level (yellow arrow) and CIAB at the L5-S1 IDL (red arrow).

and $4.7 \%$ abdominal aorta. ${ }^{[3]}$ When we review the literature, it is seen that external iliac artery is injured in endovascular interventions, ${ }^{[4]}$ whereas LCIA/ $V$ injury and at the level of L4-5 is more frequent in lumbar disc surgery. ${ }^{[5,6]}$ In this study, morphometric analysis of vascular structures likely to be injured in CT angiography was performed by considering lumbar disc surgery associated vascular injuries.

\section{MATERIALS AND METHODS}

The study was retrospectively conducted. The approval was taken from GOP Taksim Training and Research Hospital ethical committee. One hundred patients who had CTA for any reason between January 2016 and January 2018 in hospital radiology archive participated in the research. In the examinations of the patients, aorta bifurcation $(A B)$, right and left common iliac artery (R/LCIA) and vein (R/LCIV), and localization of common iliac artery bifurcation $(C I A B)$ were investigated. Localizations and degrees were measured by accepting the line passing through the midline of intervertebral disc as $0^{\circ}$ (12 o'clock). Each hour interval was accepted as $30^{\circ}$, and vascular localizations were described according to the clock positions in terms of ease of surgical use. Localizations of vascular structures at spinal vertebral body (VB) and IDL, whether there was fat plane in between anterior longitudinal ligament (ALL) were analyzed. The patients having sacralization and lumbarization and with the abdominal pathology were excluded from the study.

\section{Statistical Analysis}

The data were presented in median, minimum, maximum, frequency, and percentage. Nominal variables were evaluated with the chi-square test. Significance limit was accepted as $\mathrm{P}<0.05$ and two-way. The analyses were conducted by using the software NCSS 10 (2015. Kaysville, Utah, USA).

\section{RESULTS}

Totally 100 patients ( 14 females and 86 males) were included in the study. The mean age was $34.1 \pm 17.22$ years, and the median age was $28.5(\min 7, \max 74)$. $A B$ level was found to be $36 \%$ at L3-L4 IDL, $47 \%$ at L4 VC level, $16 \%$ at L4-L5 IDL, and $1 \%$ at L5 VC. It was found that CIAB, 4\% L4-L5 IDL, was at I\% L5 VB level, 64\% L5-SI IDS and 20\% SI VB (Fig. I).

The location of RCIA in 4-L5 IDL was $51 \%$ at 12 o'clock position and $49 \%$ at II o'clock position; $25 \%$ of fat plane was available between RCIA and ALL. It was adjacent to $67 \%$ LCIV and $8 \%$ ALL. LCIA was located in $72 \%$ at I o'clock, $26 \% 12$ o'clock, $2 \%$ I2-I o'clock positions. There was fat plane in $27 \%$ interval, LCIV in $15 \%$ interval as $56 \%$ adjacent to ALL, II\% thicker than $3 \mathrm{~mm}$. LCIV was progressing $30 \%$
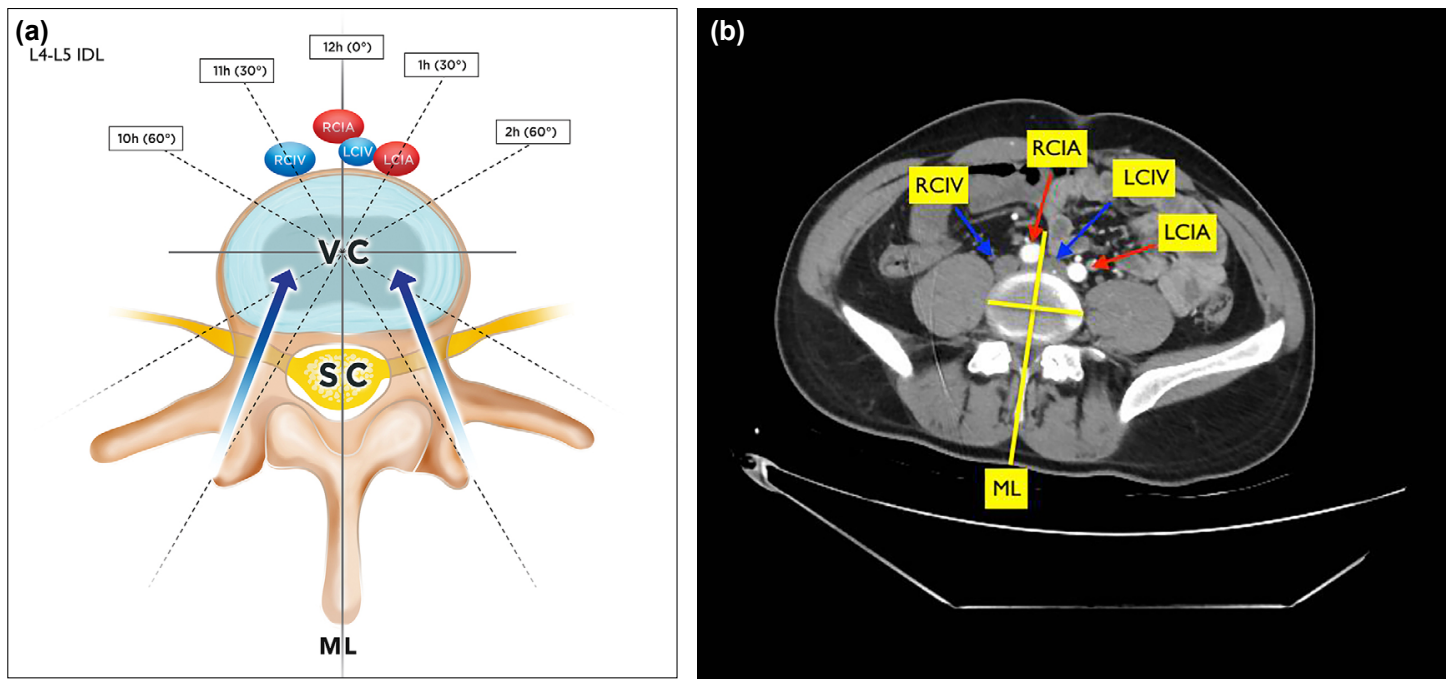

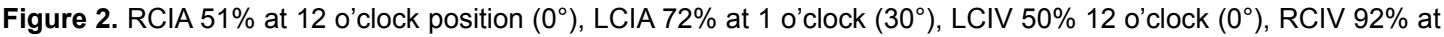
11 o'clock $\left(30^{\circ}\right)$ were located at L4-L5 IDL (a). A 30-year-old man; axial CTA image demonstrates RCIA, RCIV, LCIV, and LCIA localization at the L4-L5 IDL (b). (ML: Midline). 
Table I. L4-L5 level

\begin{tabular}{lcccccc}
\hline 0'clock & II & 10 & I2 & I & I2-I & I2-I-2 \\
\hline RCIA & $49 \%$ & - & $51 \%$ & & & \\
RCIV & $92 \%$ & $8 \%$ & - & & & \\
LCIA & & - & $26 \%$ & $72 \%$ & $2 \%$ & \\
LCIV & $30 \%$ & $1 \%$ & $50 \%$ & $1 \%$ & & $18 \%$
\end{tabular}

RCIA: Right common iliac artery; RCIV: Right common iliac vein; LCIA: Left common iliac artery; LCIV: Left common iliac vein.

Table 2. L4-L5 level

\begin{tabular}{lccc}
\hline L4-L5 level & Fatty tissue & LCIV & Adjacent to ALL \\
\hline RCIA & $25 \%$ & $67 \%$ & $8 \%$ \\
LCIA & $27 \%(11 \%>3 \mathrm{~mm})$ & $15 \%$ & $56 \%$ \\
RCIV & $97 \%$ & & $3 \%$ \\
LCIV & $10 \%$ & & $90 \%$ \\
\hline
\end{tabular}

RCIA: Right common iliac artery; RCIV: Right common iliac vein; LCIA: Left common iliac artery; LCIV: Left common iliac vein; ALL: anterior longitudinal ligament.

at II o'clock, 50\% I2 o'clock, I\% I o'clock, I\% 2 o'clock, at 18\% disc level at 12-I-2 o'clock position transversely. At this level, the distance between LCIV and ALL was very close, and no fat plane was found. RCIV was located $92 \%$ at II o'clock, 8\% II o'clock position. While 97\% fat plane was from ALL, 3\% was adjacent to ALL. In posterior approach at L4-L5 ID level, 49\% RCIA at II o'clock position, 92\% RCIV, at 12 o'clock position 50\% LCIV, 9\% LCIA, and $51 \% \mathrm{RCIA}$ and $67 \% \mathrm{LCIV}$ in between were available. At I o'clock position, 47\% LCIA, 19\% LCIV were located (Fig. 2a,
Table 3. L5-SI level

\begin{tabular}{lccccccc}
\hline 0'clock & 9 & 10 & II & 12 & I & 2 & I2-2 \\
\hline RCIA & & $63 \%$ & $36 \%$ & & & & \\
RCIV & $48 \%$ & $47 \%$ & $5 \%$ & & & & \\
LCIA & & & & $1 \%$ & $27 \%$ & $72 \%$ & $1 \%$ \\
LCIV & & & & & $26 \%$ & $70 \%$ & \\
\hline
\end{tabular}

RCIA: Right common iliac artery; RCIV: Right common iliac vein; LCIA: Left common iliac artery; LCIV: Left common iliac vein.

Table 4. L5-SI level

\begin{tabular}{lcccc}
\hline L5-SI level & Fatty tissue & RCIV & LCIV & Adjacent to ALL \\
\hline RCIA & $20 \%$ & $17 \%$ & - & $63 \%$ \\
LCIA & $92 \%$ & - & - & $8 \%$ \\
RCIV & $60 \%$ & - & - & $40 \%$ \\
LCIV & $3 \%$ & - & - & $97 \%$ \\
\hline
\end{tabular}

RCIA: Right common iliac artery; RCIV: Right common iliac vein; LCIA: Left common iliac artery; LCIV: Left common iliac vein; ALL: anterior longitudinal ligament.

b). When L4-5 IDS is compared in terms of the fat plane existence from ALL, LCIA was located more safely than RCIA $(p<0.001)$. However, there was no difference between RCIV and LCIV $(p=0.08 I)$ (Table I and 2).

At L5-SI IDL, RCIA was located $63 \%$ at 10 o'clock, $36 \%$ I I o'clock, I\% 9 o'clock position. Also, 20\% fat plane was available from ALL, $63 \%$ adjacent to ALL, and there was $17 \%$ RCIV from ALL. LCIA was located $72 \%$ at 2 o'clock, I\% at I 2 o'clock, $27 \%$ at I o'clock, in I\% cases at I2-I-2 o'clock
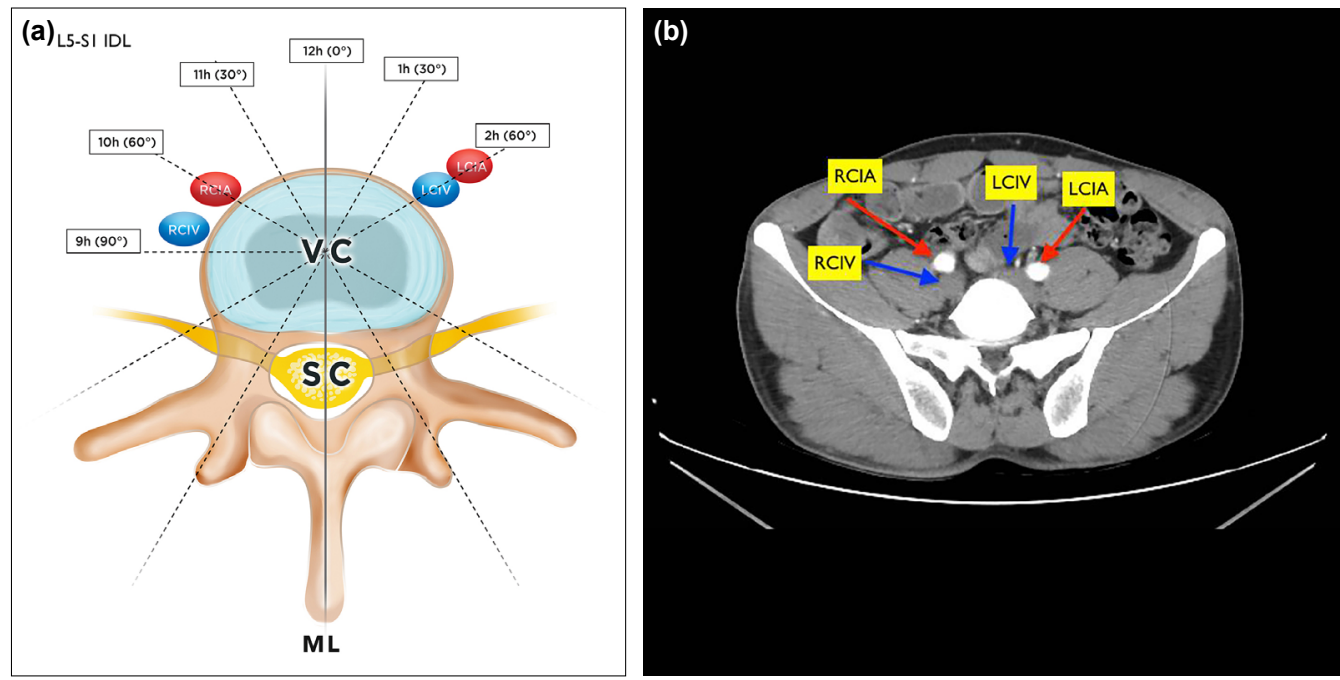

Figure 3. RCIA $63 \%$ at 10 o'clock position $\left(60^{\circ}\right)$, LCIA $72 \%$ at 2 o'clock $\left(60^{\circ}\right)$, LCIV $70 \% 20^{\prime}$ clock $\left(60^{\circ}\right)$, RCIV $48 \%$ at 9 o'clock $\left(90^{\circ}\right)$ were located at L5-S1 IDL (a). A 40-year-old man; axial CTA image demonstrates RCIA, RCIV, LCIV, and LCIA localization at the L5-S1 IDL (b). 
positions transversely. There was $92 \%$ LCIV from ALL. RCIV was located $48 \%$ at 9 o'clock position, $47 \%$ at 10 o'clock position, $60 \%$ fat plane from ALL was available. LCIV was located $70 \%$ at 2 o'clock position, $26 \%$ I o'clock position, $92 \%$ no fat plane from ALL was available and located close to ALL (Fig. 3a, b). When L5-SI IDS was compared in terms of fat plane existence from ALL, RCIA was more safely located than LCIA $(p<0.00 I)$. Similarly, RCIV was more safely located than LCIV $(p<0.001)$ (Table 3 and 4).

\section{DISCUSSION}

Among spinal surgical interventions, vascular injury is the most probable and most common lumbar disc surgery (LDS) in the literature. Vascular injury probability after LDS is between $0.05 \%$ and $0.1 \% .^{[1,3,7,8]}$ In acute stages, vascular injuries result in shock status and death. In chronicle stages, it results in pseudoaneurysm and arteriovenous fistula. The findings in acute and chronicle stages after injury can be listed as especially hypotension and tachycardia, active bleeding at disc distance, and decrease in hemoglobin level, abdominal tightness, and abdominal pain. In chronicle stages, in addition to arteriovenous fistula and pseudoaneurysm, findings of abdominal murmur, abdominal pain, abdominal bulk, cardiac failure arise. $[1,3,5,7,8]$ When lumbar disc is excised, disc curette or forceps destroys the integrity of annulus fibrosis and ALL, and causes vascular injury by passing front border of vertebra corpus. These injuries most frequently occur in discectomies at L4-5, and generally CIA and CIV get injured. In $43.8 \%$ of vascular injuries, bleeding can be recognized from disc distance. ${ }^{[9]}$ Therefore, vital findings such as preoperative blood pressure and heart rate should be carefully monitored. The most significant step in treatment is being suspicious about vascular injury. In their case presentation, Serhat et al. notified that there was bleeding on LCV posterior wall, and this area was primarily repaired. ${ }^{[10]}$ The primary vascular repair in the treatment is $57 \% .{ }^{[9]}$ While primary repair is in the foreground in lacerations, arteriovenous fistula and endovascular intervention in pseudoaneurysms are preferred in chronicle stages and include $43 \%$ of the treatment. ${ }^{[9]}$

In two different cadaver studies, Khamanarong et al. ${ }^{\left[{ }^{[I]}\right]}$ found $A B$ at $70.1 \%$ L4 VB level, Pirró et al. ${ }^{[2]}$ found at $50 \%$ L4 VB, $39 \%$ L5 VB level. In their MRI study, Vaccaro et al. ${ }^{[12]}$ noted that the case that $A B$ is at $L 4 \mathrm{VC}$ level in supine position at $73 \%$ level, $60 \%$ in prone position is related to the movement of bifurcation toward cranial. In our study, $A B$ level was determined at $36 \%$ L3-L4 IDL, 47\% L4 vertebra corpus level. According to these results, in line with the literature, $A B$ progresses for L4-5 IDL at the rate of $16 \%$ in addition to being at the level of L3-4 IDL and L4 VC substantially. At the levels of L4-5 IDL or more, there is the probability of large vein injuries such as aorta and vena cava.

Jung et al. ${ }^{[3]}$ notified five patients L4-5 disc hernia and two patients L5-SI disc hernia, three RCIA (all L4-5 IDL), four LCIA (two of them L4-5, two of them L5-SI) injury in seven disease series. In our findings, there were $25 \%$ fat plane between RCIA and ALL at L4-5 IDL, 67\% LCIV, LCIA 56\% adjacent to ALL, $27 \%$ fat plane in interval and $11 \%$ thicker than $3 \mathrm{~mm}$, LCIV $15 \%$ in interval.

At this level, the distance between ALL and LCIV was very close, and no significant fat plane was found in interval. There was $97 \%$ fat plane from RCIV, and RCIA was more closely located to ALL than LCIA at L4-L5 ID ( $<<0.001)$. There was $67 \%$ LCIV from ALL. RCIA $51 \%$ and LCIV $50 \%$ were in midline, meanly at 12 o'clock position, LCIV was localized between ALL and RCIA. According to these results, it can be considered that LCIA was in a safer position at L4-5 level and pituitary punch had a higher probability of injuring and touching RCIA or LCIV localized between RCIA after passing ALL when they are compared in terms of fat plane existence between vascular structures and ALL. Vaccaro et al. ${ }^{[2]}$ notified that LCIV was closer to ALL than other vascular structures at L4-L5 level, and the same case continued at L5-SI. In our results, there was no significant difference between LCIV and RCIV at L4-5 IDL $(p=0.08 I)$ but LCIV was closely located to ALL at $L 5-S I$ level $(p<0.00 I)$. There was $20 \%$ fat plane between RCIA and ALL at L5-SI IDS, adjacent to ALL at the rate of $63 \%$ and there was $17 \%$ RCIV from ALL. There was no $92 \%$ fat plane between LCIV and ALL, and it was in an adjacent position, while there was $60 \%$ fat plane between ALL and RCIV. When compared in terms of fat plane existence from ALL at L5-SI, RCIA was more safely located than LCIA $(p<0.00 \mathrm{I})$. Similarly, RCIV was more safely located than LCIV $(p<0.00 \mathrm{I})$. In three disease postmortem study of Ertan et al., ${ }^{[13]}$ injuries were as follows: $4 \mathrm{~cm}$ distal from RCIA bifurcation due to the surgery performed because of left L5-SI, L4-5-disc hernia in a case, 0.5 distal from LCIA bifurcation in a surgery performed due to L4-5 disc hernia in another case and LCIV injury, thirdly tear associated injury in micro-discectomy for L3-4 disc hernia around infrarenal aorta in two separate areas at left lateral occurred. At L4-L5 IDL, RCIA was located at $51 \% 12$ o'clock position (in midline), at $49 \%$ I I o'clock position (at $30^{\circ}$ right), LCIA was at $72 \%$ I o'clock (at 300 left), at 26\% 12 o'clock (in midline) position. According to the results in our study, the course of LCIA is mostly at the left side of midline and adjacent to ALL. On the other hand, the course of LCIV was in midline with transverse extension and adjacent to ALL in a long segment and no fat plane was found in between. At L4-L5 level, vascular structures were located in both sides of midline within $30^{\circ}$ angles. At L5-SI IDL, RCIA was located at $63 \% 10$ o'clock, 36\% II o'clock, LCIA $72 \% 2$ o'clock position, $27 \%$ I o'clock, RCIV at $48 \% 9$ o'clock, $47 \% 10$ o'clock. LCIV was located at $26 \%$ I o'clock position. At L5-SI level, vascular structures were located within $0^{\circ}-90^{\circ}$ angle at the right of midline, within $0^{\circ}-60^{\circ}$ angle at the left. In some of the cases presented in the literature, injuries are seen in the vascular structures across the surgical approach side. It can be emphasized that not the intervention side but the tendency in disc distance is important in terms of vascu- 
lar injury although the location of vascular structures to IDL are not stated.

At L4-L5 level, the distance of disc interval anterior face to main iliac arteries is smaller than $5 \mathrm{~mm}$ in $66 \%$ of the females and $49 \%$ of the males. It is found to be smaller than $5 \mathrm{~mm}$ at $23 \%$ of the females and $19 \%$ of the males at L5-SI. It has been reported that this has not changed in the event of providing prone position to the patients. ${ }^{[14]}$ In our study, in the comparison of fat plane between vascular structures and ALL, LCIA at L4-L5 level $(p<0.00 I), R C I A$ at L5-SI level $(p<0.00 I)$ were located remotely from ALL. LCIA was II \% thicker than $3 \mathrm{~mm}$ and fat plane was available in $27 \%$ interval. There was $3 \mathrm{~mm}$ or less fat planes in other veins and disc levels.

When bilateral lumber artery extensions have been observed at L3-L4, L4-L5 at L5-SI levels, minimum at one level, 55\% lumbar artery thicker than $2 \mathrm{~mm}$ was determined. Lumber artery thickness could not be seen thinner than $2 \mathrm{~mm}$ or with ATC $45 \%$ at all levels. It was seen that lumber arteries were moving through bilateral posterior of roots and from upper bound of foramen to spinal canal. A surgeon can encounter with this extension in especially endoscopic and far lateral approaches to disc distance, but development of bleeding and complication after coagulation is not considered. Our limitations in this study are the small number of patients, the examinations performed only in supine position and in CTA, and the ignorance of intervertebral disc pathologies of the patients.

In terms of vascular injuries that are spinal surgeon's "nightmare," RCIA is located in midline and within $30^{\circ}$ angle at the right at L4-5 IDL. LCIV is found between RCIA and ALL. LCIA is located within $60^{\circ}$ angle at left at L5-SI, very close to ALL. The possibility of an injury is high. It should be kept in mind that LCIV can progress adjacently to ALL and transversely along L4-5 ID level. In terms of vascular injuries, positions of vascular structures and fat plane between those structures and ALL play a significant role based on the results of the literature and our results. However, we can state that the most important point is the depth of disc forceps and tendency toward the midline.

\section{Acknowledgment}

Thanks to Sevim Purisa for statistical evaluation and Kemal Hayıt for illustration.
Conflict of interest: None declared.

\section{REFERENCES}

1. Erkut B, Unlü Y, Kaygin MA, Colak A, Erdem AF. Iatrogenic vascular injury during to lumbar disc surgery. Acta Neurochir (Wien) 2007;149:511-5. [CrossRef]

2. Vaccaro AR, Kepler CK, Rihn JA, Suzuki H, Ratliff JK, Harrop JS, et al. Anatomical relationships of the anterior blood vessels to the lower lumbar intervertebral discs: analysis based on magnetic resonance imaging of patients in the prone position. J Bone Joint Surg Am 2012;94:108894. [CrossRef]

3. Jung HS, Kim DJ, Kim HS, Lee HK, Choi SJN, Chung SY. Vascular Complications Related to Posterior Lumbar Disc Surgery. Vasc Specialist Int 2017;33:160-5. [CrossRef]

4. Awan MU, Omar B, Qureshi G, Awan GM. Successful Treatment of Iatrogenic External Iliac Artery Perforation With Covered Stent: Case Report and Review of the Literature. Cardiol Res 2017;8:246-53. [CrossRef]

5. Döşoğlu M, Iş M, Pehlivan M, Yildiz KH. Nightmare of lumbar disc surgery: iliac artery injury. Clin Neurol Neurosurg 2006;108:174-7.

6. Goodkin R, Laska LL. Vascular and visceral injuries associated with lumbar disc surgery: medicolegal implications. Surg Neurol 1998;49:35870. [CrossRef]

7. Papadoulas S, Konstantinou D, Kourea HP, Kritikos N, Haftouras N, Tsolakis JA. Vascular injury complicating lumbar disc surgery. A systematic review. Eur J Vasc Endovasc Surg 2002;24:189-95. [CrossRef]

8. Keskin M, Serin KR, Genc FA, Aksoy M, Yanar F, Kurtoglu M. Iatrogenic major vascular injury during lumbar discectomy: report of three cases. Turk Neurosurg 2013;23:385-8.

9. van Zitteren M, Fan B, Lohle PN, de Nie JC, de Waal Malefijt J, Vriens PW, Heyligers JM. A shift toward endovascular repair for vascular complications in lumbar disc surgery during the last decade. Ann Vasc Surg 2013;27:810-9. [CrossRef]

10. Alptekin GS, Hüseyin S, Yüksel V, Ozdemir AC, Canbaz S. A Complicated Iliac Vascular Injury Due to Lumbar Disc Surgery. Kosuyolu Heart J 2014;17:187-8.

11. Khamanarong K, Sae-Jung S, Supa-Adirek C, Teerakul S, Prachaney P. Aortic bifurcation: a cadaveric study of its relationship to the spine. J Med Assoc Thai 2009;92:47-9.

12. Pirró N, Ciampi D, Champsaur P, Di Marino V. The anatomical relationship of the iliocava junction to the lumbosacral spine and the aortic bifurcation. Surg Radiol Anat 2005;27:137-41. [CrossRef]

13. Ertan A, Oz H, Birgen N, Hanc1 M, Turan N. The role of the anesthestologist at the vessel injury because of spinal surgical procedure. J For Med 2006;20:24-8.

14. Ganesan C, Petrus L, Ross IB. Regarding the possibility of anterior vascular injury from the posterior approach to the lumbar disc space: an anatomical study. Spine (Phila Pa 1976) 2012;37:E1371-5. [CrossRef] 


\section{ORİIINAL ÇALIŞMA - ÖZET}

\section{Bilgisayarlı tomografi anjiyoda, posterior disk cerrahisinde önemli vasküler yapıların morfometrik analizi}

\section{Dr. Emre Muhittin Altunrende, ${ }^{1}$ Dr. Elif Evrim Ekin ${ }^{2}$}

${ }^{1}$ Sağlık Bilimleri Üniversitesi, Gaziosmanpaşa Taksim Eğitim ve Araştırma Hastanesi, Beyin ve Sinir Cerrahisi Kliniği, İstanbul

${ }^{2}$ Sağlık Bilimleri Üniversitesi, Gaziosmanpaşa Taksim Eğitim ve Araştırma Hastanesi, Radyoloji Kliniği, İstanbul

AMAÇ: Lomber disk cerrahisi başta olmak üzere spinal bölgeye yönelik tüm prosedürlerde damar yaralanmaları nadir görülmekle birlikte hayati öneme sahiptir. Biz çalışmamızda abdominal aortaya yönelik bilgisayarlı tomografi anjiyo (BTA) çekilen hastalarda iliak arter ve venin seyrini, intervertebral disk mesafeleri ile olan ilişkilerini morfometrik olarak araştırdık.

GEREÇ VE YÖNTEM: Bu çalışma geriye dönük olarak yapıldı. Herhangi bir nedenle BTA çekilen 100 hasta çalışmaya alındı. Hastaların BTA incelemelerinde aort bifurkasyonu $(A B)$, sağ ve sol kommon iliak arter (R/LCIA) ve ven (R/LCIV), kommon iliak arter bifurkasyonunun (CIAB) lokalizasyonu araştıııldı. Bu vasküler yapıların spinal vertebra body (VB) ve interverteral disk seviyesinde (IDL) lokalizasyonu, anterior longitudinal ligaman (ALL) ile aralarında yağ plan olup olmadığı araştırıldı.

BULGULAR: L4-5 IDL'de RCIA \%5I saat 12 hizasında ve \%67 oranında ALL ile arasında RCIV bulunmaktaydı. LCIA \%72 saat I hizasında ve \%47 ALL'ye yapışık, \% II arada yağ planı mevcut iken \% I4 arada LCIV bulunmaktaydı. RCIV \%92 saat II hizasında yerleşmekte, \%97 ALL ile arasında yağ plan bulunmamaktaydı. LCIV \%80 saat II-12 hizasında, \% I8 transvers olarak saat I2-1-2 boyunca yerleşmekte ve hastaların tümünde ALL ile arasında yağ plan bulunmamakta, ALL'ye yakın yerleşimliydi. LCIA L4-5 IDL ALL'ye RCIA göre daha uzaktır ( $p<0.00$ I). L5-SI IDL'de RCIA \%63 saat 10 hizasında ve $\% 63$ oranında ALL ile arasında yağ plan bulunmamaktaydı. LCIA, \%72 saat 2 hizasında, \%92 ALL ile arasında LCIV bulunmaktaydı. RCIV \%95 saat 9- I0 hizasına yerleşmekte, \%60 ALL ile arasında yağ plan bulunmaktaydı. LCIV, \%96 saat I-2 hizasında yerleşmekte, \%92 ALL arasında yağ plan bulunmamakta, ALL'ye yakın yerleşimliydi. RCIA L5-SI IDS ALL'ye LCIA göre daha uzaktır ( $p<0.00$ I). CIV'ler L4-5 IDS ALL uzaklıkları açısından fark yoktur ( $p=0.08)$. L5-SI IDL RCIV ALL'ye LCIV'ye göre daha uzaktır $(p<0.00 I)$.

TARTIŞMA: L4-5 IDL RCIA orta hatta ve sağa $30^{\circ}$ lik açı içerisinde yerleşmekte, ALL ile aralarında LCIV bulunmakta, bu seviyede olan bir damar yaralanması vene veya arter-ven kompleksine bağlı olma olasılığı yüksektir. L5-SI IDL ise LCIA sola $60^{\circ}$ hizasında, LCIV ile birlikte ALL'ye çok yakın konumlanmıştır. CIA'lar ALL ile aralarında yağ plan bulunması ve ALL'ye uzaklığı karşısaştıııldığında L4-L5 IDL'de RCIA ( $<<0.00$ I), L5-SI IDL'de LCIA $(p<0.00$ I) ALL'ye uzak yerleşimliydi ve daha korunaklı bir pozisyonda olduğu söylenebilir. LCIV'nin L4-5 ID seviyesi boyunca ALL'ye yapışık ve transvers ilerleyebileceği akılda tutulmalıdır.

Anahtar sözcükler: İyatrojenik vasküler yaralanma; iliak arter yaralanması; lomber disk cerrahisi; spinal cerrahi.

Ulus Travma Acil Cerrahi Derg 2019;25(2): 105-I 10 doi: 10.5505/tjtes.20।8.49274 